\title{
AUSTIN SCOTT AND \\ THE "SEMINARY IN HISTORY"
}

\author{
BY L. ETHAN ELLIS
}

THE following article adds a minor footnote to the story of historical teaching in the United States and reminds the Journal's readers of a well-loved teacher and former President of Rutgers. Professor Ellis, a member of the University staff since 1928, has written also (Alumni Monthly, April, I938) of James Westfall Thompson, '92, another important figure contributed by Rutgers to the historical profession.

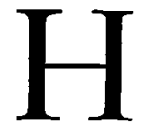

OUSED BETWEEN THE covers of a slightly dog-eared black ledger in the Library files is a partial picture of an interesting educational technique. Here, on two hundred-odd pages of varied but generally legible and often literate undergraduate script, are recorded the minutes of a seminar in American history which brought together Dr. Austin Scott, then professor of History, Political Economy, and Public Law, and sundry members of the College Classes of I 889 and I $890 .{ }^{1}$ The record at once illustrates in minor fashion the Atlantic migration of German university techniques, describes a then unusual but not unique application of those techniques to undergraduate instruction, and reflects the methods and personality of a great teacher whose impress is still vivid on the lives of many men of Rutgers.

The seminar, now characteristic of American graduate schools, is an import from Germany, where its methodology developed incidental to the training of priestly teachers. ${ }^{2}$ By an easy transition the approach was adapted from theology to philology and later borrowed for training in other fields. The first historical seminar was apparently launched by Leopold von Ranke at the University of

\footnotetext{
1 Dr. Scott (August 10, 1848 -August 15, 1922; A.B. Yale, 1 869, A.M. Michigan, 1870 , Ph.D. Leipzig, I 873 , on a dissertation entitled "Relations of Macedon to Rome in the War with Carthage") was appointed to the Rutgers staff in January, 1883 . He was inaugurated President in February, I 891 , served for fifteen years, and after resigning in 1906 devoted himself for another decade and a half to grounding successive generations of students in the fundamentals of the American constitutional system. Allen Johnson and Dumas Malone (eds.), Dictionary of American Biography (20 vols, and an index vol., New York, 1928-1937), 7, pp. 486-487; Targum, December 1, I 890 .

" Herbert Baxter Adams, New Methods of Study in History. Johns Hopkins University Sindies in Historical and Political Science, Series 2, No. 2 (Baltimore, 1884), p. $6{ }_{4} \mathrm{ff}$., outlines the evolution of the seminar method.
} 
Berlin about I 830; the practice of students meeting intimately with their professors for the joint examination and interpretation of historical texts had become well established by the time Americans began in numbers to seek European university training. Germanschooled American teachers of history began using the seminar method with both graduates and undergraduates shortly after the close of the Civil War. ${ }^{3}$ Charles Kendall Adams seems to have first practiced the technique with Michigan seniors in 1869 . By I 876 the product of Henry Adams' seminar with "advanced students" at Harvard had found its way into print. In the same year Austin Scott launched at the Johns Hopkins University a program to be described below. Two years later Herbert Baxter Adams was using the method with undergraduates at the Hopkins, repeating the experience with Smith College seniors in 1879 , I880, and I88I. By the latter years Ephraim Emerton had introduced Harvard undergraduates to the "practical" method, an adaptation of the German seminar, and by the mid-'8os Pennsylvania, Cornell, Wisconsin, Nebraska, and California could also boast of "seminaries."

The Baltimore University founded by the bounty of wealthy bachelor Johns Hopkins opened its doors for instruction in 1876 . During the preceding six months President Daniel Coit Gilman had chosen twelve "associates," ranking below full-fledged staff members. Austin Scott (appointed April I 7) was one of these." While a student at Leipzig young Scott had begun assisting the historian George Bancroft, then Minister to Germany, with the researches underlying the later stages of the preparation of that scholarly diplomat's monumental history of the United States. He also served as Bancroft's private secretary during the Franco-Prussian War and the formation of the German Empire. After two years as an instructor in German at Michigan ( $1873^{-1} 875$ ) Scott resumed in Washington his work with Bancroft, which continued until publication in I 882 of

${ }^{3}$ This brief survey is based upon the following near-contemporary accounts: Adams, op.cit., pp. 87-109; G. Stanley Hall (ed.), Methods of Teaching History (Boston, 1 886), Pp. 3I-60, II 4, II 7, I 2 I, I 79, 2 I 3.

4 Scott's Baltimore connection is described in Adams, op.cit., pp. 97-100; W. Stull Holt (ed.), Historical Scholarship in the United States, 1876-190I: As Revealed in the Correspondence of Herbert B. Adams. Johns Hopkins University Studies in Historical and Political Science, Series 56, No. 4 (Baltimore, 1938), p. 13; John C. French, $A$ History of the University Founded by Johns Hopkins (Baltimore, 1946), p. 346; Herbert B. Adams: Tributes of Friends (Baltimore, 1902), pp. 32, 40, 57. 
the two-volume History of the Formation of the Constitution of the United States. ${ }^{5}$

During his associateship at Hopkins (I 876-I 882) Scott inaugurated the historical seminar, distilling and retailing the results of his own researches in the sources of the American constitution and of his contacts with Bancroft. Herbert Baxter Adams, then a post-doctoral fellow, shortly to be Scott's successor as the leading historical practitioner at the University, and himself a member of the seminar, has left us his own description:

Dr. Scott, who spent most of his time in original research in the library of the state department and with Mr. Bancroft in his own study, came to Baltimore once a week to conduct a session of the historical seminary, which met Saturday mornings.

The same course of constitutional studies, which Mr. Bancroft and Dr. Scott had pursued together, was now reviewed by six or eight university students under Dr. Scott's instructive guidance. The seminary had the feeling that they had been admitted to Mr. Bancroft's workshop and that, by the examination of his materials and his methods, they were being taught the art of constructing history. The very manuscripts which Dr. Scott had prepared, while collecting and sifting facts for Mr. Bancroft, were shown to the seminary. Questions still unsolved were submitted to Johns Hopkins students for their consideration in company with their instructor. . . . Original papers were prepared by various members of the seminary, and written words of encouragement for work like this, came from the historian himself. The feeling was thus engendered that, in some slight ways, the seminary was contributing to the great volume of United States History. . . . the new methods were very simple. Instead of each man buying an expensive work of constitutional history, a set of the journals of the old congress, the Madison papers, Elliot's debates, the writings of Washington, Jefferson, Hamilton, and a few other sources of information contemporary with the formation of the constitution, were brought together upon a long table in the library of the Maryland historical society, where seminary sessions were held, and where special facilities were afforded for original research. Around this common board gathered the seminary which was composed originally of six or eight men, four of them "fellows" of the university. The director sat at the head of the board, and usually gave a short lecture or informal "talk," introductory to the discussion of specific topics which had been assigned for research during the previous week. Reports were made; papers were read; and general interest was awakened in special questions touching the origin and growth of the American constitution. . . . ${ }^{6}$

${ }^{5}$ Nine volumes of the History had been published prior to Bancroft's acceptance of the Berlin assignment. The tenth and last, in preparation of which Scott participated while in Germany, appeared in I 874 after Bancroft's return to the United States. Dict. Am. Biog., I, pp. 564-569; Targum, Dec. I, i 890 .

${ }^{6}$ Adams, op.cit., pp. $98-99$. 
The new professor apparently lost little time in transferring Hopkins' methods to New Brunswick. The College catalogue for I $882-$ 1883 indicated a vacancy in the Voorhees Professorship. Its single paragraph descriptive of history offerings stated that "Instruction is given by text-books, lectures and conversational discussions." The appearance of Scott's name in the catalogue of I 883-I 884 coincided with considerably elaborated course descriptions and a sharp alteration in methods. Sophomores were to investigate special topics and to be given instruction "on the sources of history." Juniors, familiarizing themselves with the philosophy of history via Francois Pierre Guillaume Guizot's History of Civilization in Europe would write essays. And for

students of the senior year and for graduates, the Professor of History has formed a class in which the methods of study will be those of the so-called historical "Seminary." The following may serve as examples of the nature of the subjects proposed for investigation in this class:

Methods of historical inquiry; fields open to the American student for original research; the nature of local government in England and in America; comparative study of local institutions in the United States; the English Government in its theory and methods.

It thus becomes fairly obvious, although documentary evidence from class records is not available, that Rutgers seniors were among the earliest American undergraduates to be exposed to the seminar method of instruction. By mid-September, I 888, then, when fifteen men (nearly half of the forty listed as graduates of the Class of I 889) ${ }^{7}$ answered to the first roll-call, the methods exemplified in our source-volume had become well-known along the Raritan.

The class met forty-three times between September 19, I 888, and the last session to be described, on March 20, I 889. ${ }^{8}$ Its sessions were held on Wednesday and Thursday of each week, at the "third hour," I I a.m. Meetings were held in "Dr. Scott's room," to the left of the main entrance of Old Queens, or in the Library, then housed in Kirk-

${ }^{\top}$ Richard T. Greene (comp.), Class of 1889 , Rutgers College, History to rgr6 (n.p., n.d.); Catalogue of the Officers and Alumni of Rutgers College (Originally Queen's College) in New Brunswick, N.J., t776 to 1916 (Trenton, 1916), pp. 201-203. Sixteen took the course in 1889 - 1890 .

${ }^{8}$ The volume's concluding pages chronicle the thirtieth session of the 1889 -1 890 group on January 30 , 1890 , but the entry for the day, containing an advance assignment, makes it clear that the end of our volume was not the end of the story. The following description of class organization and activities is based on the record of both 1888 1889 and $1889-1890$. 
patrick Chapel. Student secretaries served in rotation and each day's record was carefully scrutinized at the following session; seldom was a scribe allowed to enter his minutes without amendment. A reader of the I950's, perusing the sixty-year-old pages, can construct a fairly clear picture of a bygone day, even though its elements filter through the hands and minds of a score-and-a-half of student reporters. The picture is one of close and easy but respectful relations between students and a mature and able scholar, whose ideas have taken shape and some rigidity, but whose methods and approach continue flexible. The students were expected to work and seem to have expected to do so. This was not taken for granted, however, as witness occasional professorial interrogations as to what works had been consulted on particular topics and at least one dry suggestion "that still further work be done upon the subjects in hand." Student procrastination, moreover, was not unknown, for once, when papers on "The organic relations of the states to the German government" were called for, "Mr. Van Arsdale reported progress. Mr. Mabon and Mr. Mayou reported papers. Mr. Schenck made no report." And again: "The reports concerning Conn. and Mass. not being fully prepared, Maryland was called for," with more adequate response.

Instruction began at the first session, with the usual dissertation on the scope and method of the course, followed by some general remarks on the study of history, and concluding with a motto from Demosthenes, suggested as a class model, whose Greek text the secretary of the day transcribed without difficulty and translated somewhat freely as follows: "For the one who is ever claiming that the laws and the constitution are his concern must at least give this proof of it that the joys and the sorrows of the masses are his." Scott then launched into a formal lecture entitled "A General view of Constitutional growth in the United States," which occupied most of the next four sessions, while work on assigned topics was in progress. In these, in occasional summary lectures interpolated in the succession of student reports, and in casual comment on these reports, are revealed many of Scott's own views on history. This first session was concluded by the assignment of a topic for class discussion at the next meeting. As outlined, the course aimed to cover during the first two terms American development down to the Civil War. (Later practitioners of Scott's craft may take wry comfort from the fact that he, like them, failed by at least a decade to reach his announced goal.) 
In the third term-not covered in our record-it was proposed to study "an Historical Drama either in English, German or French."

At the second meeting the class was divided into four sections, with assignments as follows:

I. Adoption of the constitution by the states.

Act of congress in appointing days for election.

2. Election of Washington and Adams.

3. " " Senators and Representatives.

4. Meeting of Congress and the Inauguration of Washington.

The students began disgorging the results of their labors at the sixth meeting, evidently at first by reading papers, although the minutes seem to indicate that this formality later alternated with less cut-anddried reports as the term wore on and relations between class and instructor became better established. Papers or reports usually elicited discussion by all hands, and an occasional session was devoted entirely to such interchange. The record is not clear as to the extent of student contribution to the discussion, since the minutes, while making no specific mention of student comment, often paraphrase and sometimes quote those of the instructor. Papers must have been relatively short, as two or three reports per period were not uncommon, and two marathon sessions recorded five and six student appearances respectively. While one series of reports was on the boards, another was on assignment, the work thus moving in a leapfrog pattern which maintained a degree of pressure on the class. This pressure was doubtless relieved by the occasional lengthy discussion of papers and by Dr. Scott's intermittent contributions. The reader is on the whole impressed with the skillful blending of discussion and formal presentation, to which both instructor and students contributed, a result attainable only by an experienced and adroit classroom administrator.

As indicated above, it was the announced intention to cover the history of the United States from the constitutional period to the Civil War. ${ }^{9}$ Actually, the last report was on the Clayton-Bulwer Treaty (I 850), though such topics of the I 850 s as the repeal of the Missouri Compromise, the Kansas-Nebraska legislation, and the election of 1856 had been assigned. As might be expected from Scott's

\footnotetext{
${ }^{9}$ This approach was varied somewhat with the $1889-1890$ group by an initial assignment of short papers on topics dealing with relations between central and local authority in European nations.
} 
own training and experience, the choice of topics and the orientation of discussion was heavily political and constitutional, though an effort was made (not too successfully) to keep the diplomatic story marching in step. Considerable attention was devoted to the development of governmental practices in the early days under the constitution. Certain economic questions, particularly the tariff, engaged Scott's interest and received extra-careful consideration. While the topics moved in roughly chronological order, there was no attempt to cover the whole story, unless this was done in discussion and in a fashion not made evident in the minutes. Student attention was constantly directed toward the use of primary sources, and Scott also mentioned and commented critically from time to time on contemporary works of scholarship. Like all good teachers, too, he took occasion to set current events against their historical background. The twentieth-century reader gathers the impression that the student of the I 890's took with him from the historical seminary a fair knowledge of his country's past as it had been written and evaluated in his own day. He should have carried, moreover, a well-developed concept of history as a discipline, and certain very definite attitudes toward the institutional development of his country.

These concepts and attitudes appear clearly in the pages of our source volume, despite the fact that they reach us through the medium of undergraduate reporters who, fortunately or unfortunately, are not always faithful mirrors of the professorial mind. In this instance, however, the recurrence of ideas through the reports of successive secretaries over a two-year period evidences the vigor with which they must have been expressed. The record shows Scott urging his students to search for truth through the encumbering maze of fact. This search, he held, must lead to the primary sources, the only reliable authority. References to and quotations from these sources, many of which he had personally examined, made up a fair share of his comments to the class. He urged, too, resistance of the normal tendency to inject personal opinion when drawing conclusions from facts found in the sources and, on occasion, advised care in fitting student language exactly to the available facts. On the whole, except for a few references to the "providence of God" as a disposer of events, not now so likely to receive overt mention, his canons of scholarship were those to which historians still subscribe.

His view of United States history generally paralleled the think- 
ing of his day, though he did not hesitate to differ with leading writers, including his own mentor, on particular matters. His central theme was the "federative principle," by which the normally divisive and antagonistic factors of nationalism and localism fused into a nicely-balanced amalgam in the Constitution. By their acts of ratification, the States created a "political sovereignty of national government of all the people," from which later legal secession was an impossibility. ${ }^{10} \mathrm{He}$ insisted that this principle and the Constitution in which it is embodied "excludes all but localism and nationalism. It banishes all sectionalism." This later excrescence and the concomitant assertion of State rights caused him some difficulties in logical exposition, but he emerged with a stoutly nationalist interpretation of American history in the Webster-Lincoln tradition.

Our volume then shows Scott as a nationalist and constitutionalist, legalistic in his approach, and something of a hero-worshipper. $\mathrm{He}$ is fulsome in his appreciation of Alexander Hamilton and Daniel Webster and, in a "brief review of Washington's greatness" quoted in an approving context Bancroft's "personal and private" reference to George Washington as " "the wisest man that ever lived." " (Conversely, the writer recalls very little favorable comment on Thomas Jefferson.) Like most of his contemporaries, he dealt relatively little with social and economic matters, though the tariff interested him considerably. His students learned something of diplomatic history, though neither in such depth or detail as in the politico-constitutional areas. In foreign relations Scott found himself on occasion a somewhat apologetic apologist for mid-nineteenth-century imperialism, being reported as saying, apropos the Mexican War: "However much wrong there was in the beginning of the war, wonderful results have come from it." In sum, Scott's students, like those of other teachers before and since, exposed themselves to a somewhat slanted but vigorously expressed point of view and fell heir (or victim) to the personal predilections of their instructor in scope and choice of material.

\footnotetext{
${ }^{10}$ At one session he was quoted directly, as follows, on his leading principle: " 'Our government is a living organism dominated by one principle of life - the Federative principle, which is composed of two forces-Nationalism and Localism, the welfare of the one being the interest of the other. . . ." Again a reporter paraphrased: "The federative principle is an organism, a growth, a living expression of free will, and is superior to the principles it fashions." This touchstone of historical philosophy had been developed and presented during his Hopkins period.
} 
A concluding word might be added concerning the thirty-one members of the Classes of I 889 and I 890 through whose pens much of the material for this survey has been handed down. ${ }^{11}$ Fourteen were native New Yorkers, ten were Jerseymen. Rutgers' contact with foreign missions is reflected in the fact that three (two of them Scudders) were born in India and one was a Japanese. Virginia, Iowa, and Vermont furnished the rest. Only three have left record of having attended public schools. Of those whose religious affiliations have been ascertained, fifteen claimed the Reformed Church, seven were Presbyterians, two Episcopalians, and one a Congregationalist. Later choice of professions was restricted within a fairly narrow range, with fifteen going into the ministry, eight into the law, five into education on various levels, four into business, and three into journalism. Eleven were entitled to wear the key of Phi Beta Kappa. Twenty-one continued their formal education after leaving Rutgers, and the group amassed a total of thirty-seven degrees, many of which were Rutgers A.M.s which, though not quite so easily attainable as in an earlier period, could still be acquired by presenting, not less than three years after graduation, a certificate of graduation from a school of theology, medicine, or law, a certificate of admission to the practice of either of the two latter professions, or evidence "of successful labor in that field of education or literature which may have been chosen. ..." Most labored quietly but not too prominently in their chosen fields. Few shifted means of livelihood, though four wearers of the cloth are also listed in other lines of activity, whether from economic pressures or a change of heart is not clear from the record. Several (E. W. Thompson, J. A. Liggett, and S. Ward Righter) became prominent in their religious denominations. Five were educators, four becoming High School principals and the fifth (Byron Cummings) graduated from a professorship of Classics to a succes-

\footnotetext{
${ }^{11}$ See references in Note 5, above, and O. M. Voorhees (ed.), Phi Beta Kappa General Caialogue, $1776-1922$ (Somerville, N. J., 1922). Some added material was secured from information in the Rutgersensia files of the University Library. Where more than one occupation was listed, both appear in the totals. The names of the students are given herewith, those in the Class of 1890 being in italics: H. R. Anderson, Arthur J. Collier, Byron Cummings, John TenEyck DeWitt, George V. W. Duryee, Howard W. Ennis, Garrett J. Folmsbee, George W. Glasier, M. W. Hallock, Horace S. Hawes, Irving W. Hoagland, James H. Keeling, J. A. Liggett, Charles Maar, Arthur F. Mabon, Warren A. Mayou, K. Oishi, S. Ward Righter, H. L. Rupert, Warren R. Schenck, Charles J. Scudder, Henry J. Scudder, Arthur Spaulding, Isaac Sperling, George J. Steinmetz, Jr., Elias W. Thompson, Maurice J. Thompson, E. B. Van Arsdale, John S. Van Orden, R. S. Voorhees, William D. Ward.
} 
sion of university administrative posts. The heavy preponderance of clergymen would suggest that as late as the period under consideration Rutgers was still carrying on the business of the early colleges in preparing candidates for the ministry.

This investigation leaves many gaps in our knowledge of teaching in a bygone day. Did, for example, the students arrive late for class? Did they sit with rapt attention or did they, after the manner of other, later students, allow their minds to wander? What was the nature of their examinations? Was the professor always thoroughly prepared? The record does not disclose. It does, however, restore across the years a sense of immediacy, of mutual respect and confidence between teacher and student, and of partnership in the learning process which, then as always, are of the essence of good teaching. 